\title{
Perception Based Principal Leadership Measurement: Does It Work in Pakistan?
}

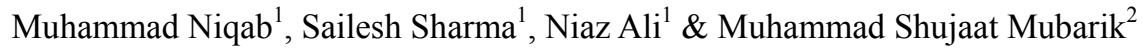 \\ ${ }^{1}$ Institute of Educational Leadership, University Malaya, Kuala Lumpur, Malaysia \\ ${ }^{2}$ Faculty of Economics and Administration, University Malaya, Kuala Lumpur, Malaysia \\ Correspondence: Muhammad Niqab, Institute of Educational Leadership, Wisma R \& D, Level-11, Jalan Pantai \\ Baru 59990, University Malaya, Kuala Lumpur, Malaysia. Tel: 60-169-109-187. E-mail: niqab2@gmail.com
}

Received: November 18, 2014 Accepted: December 19, 2014 Online Published: March 29, 2015

doi:10.5539/ies.v8n4p29

URL: http://dx.doi.org/10.5539/ies.v8n4p29

\begin{abstract}
Adequacy of relevant knowledge and interpersonal skills, interalia, are vital contributors to a successful leadership. However, leadership is not a self-centered phenomenon but followers through their actions and views profess it. Extant literature suggests teachers' and principals' perceptions as a prominent tool for measuring school leadership. This study evaluated the applicability of this leadership measure in context of Pakistani schools. Study focused on analyzing the differences between views of school principals about their own leadership attributes and as viewed by the teachers under their sub-ordination. We adopted the questionnaire developed by Sharma (2010) and Sun et al. (2014) to collect the data on leadership attributes. Total of 178 teachers and 18 principals from Secondary Schools in Pakistan responded the questionnaire. We applied independent sample t-test to analyze the data. The results showed a significant difference between perceptions of principals about their own leadership attributes and that of views by the teachers working under them. The results of the study suggest that principals in the schools under study lack the leadership skills. Further analysis revealed that most of the principals considered them good leader but their sub-ordinates opinion negated this. It shows, the principals, under study, either lacked the interpersonal skills to motivate their sub-ordinates or failed to modify the opinion of their sub-ordinates.
\end{abstract}

Keywords: school leadership, leadership attributes, principals' perception, teachers' perception

\section{Introduction}

Effective leadership always plays a momentous role in the augmenting the efficiency of an educational institute. A successful leader sets goals for the institute and utilizes all the resources for the achievement of organizational goals. To Leithwood and Riehl (2003, p. 64) "Scratch the surface of an excellent school and you are likely to find an excellent principal; Peep into a failing school and you will find weak leadership". Without setting specific goals it is impossible to bring improvement in school. According to (Cheng \& Townsend, 2000) for bringing educational change for improvement, it needs the key role of the principal. The principal always faces challenging situations to promote a culture of improvement and betterment that act up to the smallest elements, procedures and the system of an institute. Ignoring and not giving proper concentration on teaching staff potential and students' achievement major change is not possible i.e. by providing a conducive environment for teaching learning and improving teachers professional skills. Various research studies show the similar results on administering a change in education (Marmar, 2001). Extant scholastic work shows a significant and momentous relationship between principal leadership and school improvement (Hallinger \& Heck, 2011, p. 2). But leadership is less what you speak and more what your sub-ordinates speak about yourself. In Pakistan most of the studies conducted on leadership have focused the principals themselves to take their opinion about their leadership style. By doing so, it is assumed that the teacher's views are those reflected by their principals. However, studies concentrating teachers to take view about their leader, principal in this case are limited to see (Rizvi, 2010). The same is case in some other developing countries (Rizvi, 2010, p. 13; Simkins et al., 2003). Though, it is vital that a head teacher should be updated with professional skills in order to apply it for the development of staff and introducing new techniques to provide a healthy environment for teaching learning process. But this is not solely the head teacher, who will estimate his leadership capabilities. The other side of the picture is also important, that is to also take the opinion of sub-ordinate teachers (Niazi, 2012, p. 318). 


\subsection{Aim of the Contemporary Study}

This study is therefore, determined to fill this existing gap by putting side by side the opinion of teachers to evaluate leadership qualities of their own educational heads and the same leadership skills as perceived by principals rated for their own self. Another intention is to examine the difference between perceptions of principals and teachers about leadership competencies. 'What do the principals actually think for themselves and where they really stand?

\subsection{Objectives Conducting This Study}

The foremost aim of this comparative study is to ascertain the worthy views of the teachers about principal leadership attributes as leader comparing with Principal's own views regarding their own leadership qualities.

(1) What are the basic principles of leadership attributes?

(2) What are the opinions of teachers about leadership attributes of their own Principals?

(3) Is there any significant difference in opinion of principals and teachers about leadership attributes of the principals?

\section{Literature Review}

\subsection{School Leadership-An Indefinable Idea}

Various researchers tried to explain school leadership in a variety of ways. The term portrays an individual who takes initiative for bringing a change in the existing system to achieve the organizational goals. Similarly leadership is "the position or guidance of a leader and the ability to lead" (Williams, 2009, p. 30). Only possessing an office of the leader is not a guarantee for successful leadership. A successful leader has the ability to use all the available resources and develop a community of coordinated leadership, such that guiding for school improvement. A successful leaser adopts a pattern to exhibit certain acts like supervision of the subordinates. This adopted pattern determines the leadership ability of that particular leader. There are several such patterns, called types of leadership, like situational, autocratic, democratic, transactional, transformational and Lassez-Faire leadership (Dahar et al., 2010, p. 458; Mosadegh-Rad, 2003). In case of school principals , all have certain skills, which may turn them effective; these skills are transformative, managerial and behavioral(Richter et al., 2012). The possession of these skills and attributes, among other things, determine the leadership style of that particular principal. Further, it is of prime importance that a principal should possess these skills sufficient. Taking on this point, Bush (2008, p. 33) asserted that appointing administrators without adequate training is like gambling "and it is inappropriate to gamble when the losers would be children or students" cited in (Khan, 2013a, p. 47). Castelli (2000, p. 400) cited in (Baig \& Shafa, 2011, p. 1) maintain that, "Headship can clearly be seen not as some technical exercise but as being about social, moral and educational values and their playing out in action". Leadership is considering as the most significant in any institute for its effective functioning. Rising importance of school leadership, leadership behavior and organizational commitment has got more attention in recent era (Gamage \& Pang, 2003; Tatlah et al., 2011, p. 1293). Nowadays dynamic leaders are more require than ever before because they can bring change in the existing system (Tatlah et al., 2011, p. 1293).

The vital influence of the school leadership is that on the students learning and outcome. Several researchers have shown their view that school leadership has an indirect impact on students learning (Bell et al., 2003; Bossert et al., 1982; Hallinger \& Heck, 1998, 2010; Leithwood et al., 2008; Robinson et al., 2008; Witziers et al., 2003). In simple words leadership have an impact on both teaching and learning. A major area that is covered by leadership include 1) better student outcomes, 2) facilitating staff for better outcome 3) provision of the best resources to get better results.

Political leadership pass on to such type of leadership which construct alliance between different units of an institute, always welcome participation and coordination in decision-making and solving existing problems between different blocks. Cultural leadership steps to such a leadership role that motivates and encourages members to follow the organized vision and remarkable presentation. This makes up an innovative organizational culture and shifts the current values and standards of followers practicing in organization. To handle a more complex situation distributed leadership is preferred, where task responsibility is not the responsibility of a single person only but leadership team is involved (Harris, 2007). So empowering their staff to take necessary initiatives or developments within the schools. Leaders also concentrate on such steps, which are necessary for higher performance of the students (Harris, 2002). In this context the pivotal role will play by leadership to change the whole scenario (Hopkins, 2001; Hopkins \& Reynolds, 2001). This leadership will enhance it focuses on the challenging schools to raise expectations about performances (Harris, 2002). Where 
principal acts alone as an instructional leader, school improvement then wholly depends on his/her solo efforts. Today successful principals concentrate on the shared vision, conversation with staff, sharing knowledge and focus on students' achievements (Lambert, 2002). This actually shared leadership is a phenomenon which relate to collaborative working, sharing important information and collective decision making and valuing each other rather than one man show as a leader (Hoch \& Dulebohn, 2013). But Educational leadership shift in such a leadership that specify the track and worthy counsel on promoting learning, instruction and designing set of courses, emphasizes on link with education in administration, identifying educational difficulties and stress on professional improvement and betterment in instruction. A change has taken place in defining leadership and its models, as it is appearing as bringing improvement in school and consider as a reform movement, how scientific management approaches 1980s introduces to the reshaping of schools as independent learning organizations (Hallinger, 2003; Rizwan, 2011). However, various duties of principal set demanding and challenging role of the principal (Mestry \& Grobler, 2004). While for selection of a competent principal, Cranston (2002) suggested that the principals must have the skills and capacities to hold an office. To have enough skills and knowledge principals require an in-service training. (Khan, 2013b; Khan, 2004, p. 100) admits that principals in Pakistan have very inadequate professional development chances: "There are some working out plans, which provide work related training to Principals, but such programmers are organized rarely and benefits only a very short number. This usually takes place through foreign funded projects". Some studies conducted in Pakistan showed that principals working in Pakistani schools have less leadership skills or having no leadership skills at all. Similarly, opinion of teachers regarding their principal's leadership has rarely been taken into account while analyzing the leadership ability in Pakistan. Further, less empirical work on the role and impact of educational leaders in education systems is evident in Pakistan (Rizvi, 2010, p. 13; Simkins et al., 2003).At the moment there is no specific criteria to judge the performance of the head teacher in Pakistan(Khan et al., 2009). The major reason of lower leadership skills at principal level in Pakistan lays in the promotion system. Teachers are promoted as principals (leaders) without having knowledge of leadership. This results the efficiency of education system, keeping it in status quo (Alam, 2012, p. 197).

\subsection{Teachers' Perception about School Principal Competencies}

Leaders develops nation politically, economically, socially and scientifically. Two types of leadership namely administrative leadership and institutional leadership are more common. School leadership is considered as the institutional leadership, responsible for all functions within the premises of the school (Dahar et al., 2010, p. 458). For analysis of Principals' competencies various dimensions can be applied; such as perceptions of students, teachers, parents, communities. As (Scotti Jr, 1987) narrated that teachers' perceptions can be considered one of the variables in the measurement of principal competencies, which affect school outcome. Teachers' opinion about principals' headship governance is closely related to teachers' self-esteem (Hunter-Boykin et al., 1995). Luo (2004) assert that a perception of teachers highlighting principals as leaders show an important aspect to judge leader's capabilities. Further states that this observation of teachers about their heads leadership reflects how much are significant principal's skills for school upgrading. From Research it has found that this perception of teachers about principal's competencies also shows school environment \& culture. A research study conducted in U.S. (Hunter-Boykin et al., 1995) observed that majority of the heads were rated by their teachers as unproductive. This shows that there is a huge gap between perceptions of the principals' about their self and how they are portrayed by the teachers. In this context however they give a reason that since teachers do not have any leadership experiences and unable to understand the principal's position, their judgments are biased one (Banks, 1991). While referring to Hong Kong where primary teachers in their pre-service are found pessimistic about principal leadership competencies (Kin-Lee et al., 2000). While A study was conducted by (Luo et al., 2007) found that Chinese principal headship skills as alleged by the staff. In contrast numerous advanced countries where research studies on principals' abilities are found in large number, studies like this are very infrequently found in Pakistan. While considering a leadership role of the principal it is compulsory to have a close look on leadership attributes of that principal. In doing so the most reckoning reason is that school in Pakistan provides their services in large number for national students. Most studies in Pakistan stress on leadership styles instead of leadership attributes. Special arrangements should be made for the training of principals. Leadership capacity can be judged by measuring factors like Broad based \& skillful leadership, Inquire based use of information, Role and responsibility, Reflective practice and innovation as the norm in schools, high students' achievements in school (Williams, 2009, p. 34). Presently, the principal has adopted a new role as a mediator among leadership teams at school level, departmental leaders and school directors (Moos, 2012). Teachers should have full confidence in the Principal's abilities and academic achievements (Mattar, 2012, p. 527). This study is therefore determined to fill this existing gap by putting side by side the view of teachers regarding leadership qualities of their own heads and the leadership skills as perceived by principals rated for 
their own self. Another intention is to analyze the difference between views of principals and teachers about leadership skills. 'What do the principals actually think for themselves and where they really stand?'

\section{Methodology}

This is a quantitative research study comprising the following steps.

\subsection{Sample Selection}

The sample of this study comprising of the one hundred seventy eight (178) teachers selected from secondary schools in Pakistan, and eighteen (18) principals of the selected schools. All the teachers have a minimum of five years of experience working with the same principal (included in the study).

\subsection{Research Instrument}

Two questionnaires, one for teachers and one for principals were adapted by the researcher, developed by (Sharma, 2010).

\subsubsection{Questionnaire for Teachers}

Likert scale comprising of 5 points was used for the teachers which was an adapted questionnaire was titled "Attributes of My Principal". The survey instrument possesses eight dimensions and each dimension comprising five items each, so total items were forty. Dimensions are namely, Commitment, comfort, Empathy, Communication skills, Decision Making, Influence, Self-Management and Time management. Through this survey instrument teachers were asked to mark their principal's headship qualities by showing their assessment for each of the items on the scale given as under.

$1=$ Little Qualities (Never descriptive about my Principal)

2 = Somewhat Qualities (Rarely descriptive about my Principal)

$3=$ Moderate Qualities (Sometimes descriptive about my Principal)

$4=$ Strong Qualities (Usually descriptive about my Principal)

$5=$ Excellent Qualities (Always descriptive about my Principal)

\subsubsection{Questionnaire for Principals}

The instrument used for the principals was adapted questionnaire titled "My Leadership Attributes". The questionnaire consists of eight dimensions comprising five items each, total items being forty. These dimensions are Communication skills, Comfort, Empathy, Decision Making, Influence, Self-Management, Time management and Commitment. In the questionnaire a 5-point Likert scale used for the principals to rate their leadership potentials by showing their assessment with each of the items on the following scale.

$1=$ Little Qualities (Rarely descriptive about my Principal)

2 = Somewhat Qualities (Sometimes descriptive about my Principal)

3 = Moderate Qualities (Often descriptive about my Principal)

$4=$ Strong Qualities (Usually descriptive about my Principal)

$5=$ Excellent Qualities (Always descriptive about my Principal)

The reliability of the instrument was checked and determined by conducting a pilot study through thirty teachers and five principals from Secondary Schools of Pakistan. Their responses were analyzed with the aid of the split half method and it provided reliability co-efficient 0.89 and 0.87 respectively. The instrument was found reliable in order to measure the leadership attributes of school principals in Pakistan. Data collected for the study were analyzed using SPSS version 22, by performing independent sample t-test.

\section{Results}

From Table 1 it can be observed that out of 178 teachers out of which 99 teachers $(55 \%)$ are male while 79 teachers $(45 \%)$ are found as female. Also over $99 \%$ teachers are in the age group of above thirty. A majority of teachers (93.8\%) are bachelor degree holders rest are Master degree holders. It's noteworthy to see that around $87.6 \%$ of teachers have more than ten years of working experience as teachers. As stated prior that all the teachers that the researcher has considered as sample have been working in the same institute with the same principal for at least 5 years. The demographic profile of teachers reflects that the sample taken was sufficient to discuss leadership qualities of principals. 
Table 1. Demography of teachers ( $\mathrm{N}=178)$

\begin{tabular}{cccccccccc}
\hline \multicolumn{2}{c}{ Sex } & \multicolumn{3}{c}{ Age Range } & \multicolumn{2}{c}{ Qualification } & \multicolumn{3}{c}{ Experience } \\
\hline Male & Female & $<35$ & $35-45$ & $>45$ & Bachelor & Master & $<10$ & $10-20$ & $>20$ \\
\hline 99 & 79 & 1 & 125 & 52 & 167 & 11 & 22 & 128 & 28 \\
$(55 \%)$ & $(45 \%)$ & $(0.6 \%)$ & $(70.2 \%)$ & $(29.2 \%)$ & $(93.8 \%)$ & $(6.2 \%)$ & $(12.4 \%)$ & $(71.9 \%)$ & $(15.7 \%)$ \\
\hline
\end{tabular}

From Table 2 it is clear that out of 18 principals 8 principals (44.4\%) are male while 10 principals (55.6\%) are female. It's noteworthy that all the principals are in the age group over 45 years with a Master Degree and experience over ten years as principal.

Table 2. Demography of principals ( $\mathrm{N}=18)$

\begin{tabular}{ccccc}
\hline \multicolumn{2}{c}{ Sex } & Age & Academic Qualification & Experience \\
\hline Male & Female & $>45$ & Master & $>10$ \\
\hline 8 & 10 & 18 & 18 & 18 \\
$(44.4 \%)$ & $(55.6 \%)$ & $(100 \%)$ & $(100 \%)$ & $(100 \%)$ \\
\hline
\end{tabular}

From Table 3 it can be observed that principals perceive their leadership quality of commitment $(\mathrm{M}=4.16$ $\mathrm{SD}=2.445)$ as excellent while all other leadership qualities as strong. The overall rating $(\mathrm{M}=3.72 ; \mathrm{SD}=0.441)$ suggests that the principals perceive their leadership qualities as Strong. It indicates that these principals feel that they are excellent in commitments while strong in Self-Management $(\mathrm{M}=3.87 ; \mathrm{SD}=0.155)$, Influence $(\mathrm{M}=3.85$; $\mathrm{SD}=0.225)$, Communication skills $(\mathrm{M}=3.80 ; \mathrm{SD}=0.343)$, Empathy $(\mathrm{M}=3.55 ; \mathrm{SD}=0.499)$, Decision Making $(\mathrm{M}=3.52 ; \mathrm{SD}=0.503)$, Time Management $(\mathrm{M}=3.50 ; \mathrm{SD}=0.466)$ and Comfort $(\mathrm{M}=3.49 ; \mathrm{SD}=0.341)$.

Table 3. Descriptive statistics for perception of principals on their leadership attributes

\begin{tabular}{lccc}
\hline Leadership Qualities Dimensions & Mean & SD & Level \\
\hline Commitment & 4.16 & 2.445 & Excellent \\
Comfort & 3.49 & 0.341 & Strong \\
Empathy & 3.55 & 0.499 & Strong \\
Influence & 3.85 & 0.225 & Strong \\
Time Management & 3.50 & 0.466 & Strong \\
Communication Skills & 3.80 & 0.343 & Strong \\
Decision Making & 3.52 & 0.503 & Strong \\
Self-Management & 3.87 & 0.155 & Strong \\
Overall & 3.72 & 0.441 & Strong \\
\hline
\end{tabular}

From Table 4 it can be observed that overall mean for leadership qualities as perceived by teachers for the principals is 2.66 with a standard deviation of 0.741 , which indicates that leadership qualities of principals as perceived by the teachers fall in the moderate level. Besides this individual leadership qualities dimensions of Communication skills $(\mathrm{M}=2.59 ; \mathrm{SD}=1.025)$, Comfort $(\mathrm{M}=2.64 ; \mathrm{SD}=0.748)$, Empathy $(\mathrm{M}=2.69 ; \mathrm{SD}=0.763)$, Decision Making $(\mathrm{M}=2.62 ; \mathrm{SD}=0.765)$, Influence $(\mathrm{M}=2.73 ; \mathrm{SD}=0.764)$, Self-Management $(\mathrm{M}=2.68 ; \mathrm{SD}=0.889)$, Time Management $(\mathrm{M}=2.67 ; \mathrm{SD}=0.820)$ and Commitment $(\mathrm{M}=2.66 ; \mathrm{SD}=0.806)$ indicate that in all the dimensions of leadership qualities principals are rated to be in the moderate level. 
Table 4. Mean \& standard deviation for perception of teachers on leadership attributes of principals

\begin{tabular}{lccc}
\hline Leadership Qualities Dimensions & Mean & SD & Level \\
\hline Self-Management & 2.68 & 0.889 & Moderate \\
Decision Making & 2.62 & 0.765 & Moderate \\
Commitment & 2.66 & 0.806 & Moderate \\
Communication Skills & 2.59 & 1.025 & Moderate \\
Empathy & 2.69 & 0.763 & Moderate \\
Comfort & 2.64 & 0.784 & Moderate \\
Influence & 2.73 & 0.764 & Moderate \\
Time Management & 2.67 & 0.820 & Moderate \\
Overall & 2.66 & 0.741 & Moderate \\
\hline
\end{tabular}

From Table 5 we can found that there is a significant difference in opinion of teachers and perception of principals on all dimensions of leadership skills of principals. The $t$ value, $p$ value and Mean differences for Communication skills $(\mathrm{t}=4.937, \mathrm{p} \leq .05, \mathrm{MD}=1.21)$, Comfort $(\mathrm{t}=4.820, \mathrm{p} \leq .05, \mathrm{MD}=0.90)$, Empathy $(\mathrm{t}=4.639$, $\mathrm{p} \leq .05, \mathrm{MD}=0.86)$, Decision-Making $(\mathrm{t}=4.804, \mathrm{p} \leq .05, \mathrm{MD}=0.90)$, Influence $(\mathrm{t}=6.153, \mathrm{p} \leq .05, \mathrm{MD}=1.12)$, Self-Management $(\mathrm{t}=5.656, \mathrm{p} \leq .05, \mathrm{MD}=1.19)$, Time Management $(\mathrm{t}=4.20, \mathrm{p} \leq .05, \mathrm{MD}=0.83)$ and Commitment $(\mathrm{t}=5.711, \mathrm{p} \leq .05, \mathrm{MD}=1.49)$ clearly indicates that principals have over rated their leadership qualities while teachers have relatively less rated them. Principals perceive their leadership qualities as Strong while teachers have perceived these qualities to be moderate.

Table 5. Comparison of dimensions of leadership attributes

\begin{tabular}{lccccccc}
\hline \multirow{2}{*}{ Dimensions } & \multicolumn{3}{c}{ Principals } & \multicolumn{2}{c}{ Teachers } & \multirow{2}{*}{ Sig (2 tailed) } & \multirow{2}{*}{ Mean Difference } \\
\cline { 2 - 5 } & $\mathrm{M}$ & $\mathrm{SD}$ & $\mathrm{M}$ & $\mathrm{SD}$ & & & \\
\hline Communication Skills & 3.80 & .3430 & 2.59 & 1.0253 & 4.937 & .000 & 1.21 \\
Comfort & 3.49 & .3416 & 2.64 & .7848 & 4.820 & .000 & 0.90 \\
Empathy & 3.55 & .4997 & 2.69 & .7630 & 4.639 & .000 & 0.86 \\
Decision making & 3.52 & .5038 & 2.62 & .7659 & 4.804 & .000 & 0.90 \\
Influence & 3.85 & .2255 & 2.73 & .7647 & 6.153 & .000 & 1.12 \\
Self-Management & 3.87 & .1555 & 2.68 & .8893 & 5.656 & .000 & 1.19 \\
Time management & 3.50 & .4665 & 2.67 & .8208 & 4.20 & .000 & 0.83 \\
Commitment & 4.16 & 2.445 & 2.66 & 0.806 & 5.711 & .000 & 1.49 \\
\hline
\end{tabular}

From Table 6 we can observe that overall mean for leadership qualities as perceived by the principal is 3.72 with Standard deviation .44134 indicating a strong level of leadership qualities while leadership qualities as perceived by the teachers (Mean=2.66; $\mathrm{SD}=.74115$ ) indicating it as moderate.

Table 6. Descriptive statistics for leadership qualities of principals

\begin{tabular}{lccc}
\hline Category & $\mathrm{N}$ & Mean & $\mathrm{SD}$ \\
\hline Principal & 18 & 3.72 & .44134 \\
Teacher & 178 & 2.66 & .74115 \\
\hline
\end{tabular}

Results of independent $\mathrm{t}$ test from Table 7, show $\mathrm{t}$ value $5.964(\mathrm{p} \leq .05)$, that reflects that there is a prominent difference between opinion of principal about their own leadership attributes and perception of teachers about their principals leadership skills. Observing the Mean difference of 1.06 it can be commended that principals 
have rated themselves more than as they are rated by their teachers.

Table 7. Independent sample $t$ test for leadership qualities of principals

\begin{tabular}{|c|c|c|c|c|}
\hline Means Compared & $\mathrm{t}$ & $\mathrm{df}$ & Sig (2 tailed) & Mean Difference \\
\hline Leadership Qualities & 5.964 & 194 & .000 & 1.06 \\
\hline
\end{tabular}

$* \mathrm{p} \leqslant .05$.

\section{Discussion}

The results of this study reflect that principals were found optimistic about their leadership role whereas the teachers' opinions about the leadership attributes of their principals are just reasonable. Throughout assessment of the eight dimensions of leadership qualities, the teachers have rated their own principals to have reasonable leadership qualities, which draw a distinction with other studies. Findings of this study do not match the same results as obtained from the study which was conducted by (Hunter-Boykin et al., 1995) in U.S., which reveals that $67 \%$ of the principals working in different institutions were considered unproductive by their teaching staff. While This contemporary study has brought different results of the research studies conducted in Hong Kong (Kin-Lee et al., 2000), in China (Luo et al., 2007) and in Nigeria (Arikewuyo, 2007). While discussing principals' own perceptions about their leadership awareness, they make excellent in a sense of commitment and strong in the rest of the seven dimensions. However they are rated just moderate in all seven possessing attributes. The question arises that whether they are unaware about their own self? This study showed that principals should make themselves optimistic in the light of their personal traits. It signifies that there is a huge breach between principals' true self and they appeared stature to followers.

This study focused on ascertaining the awareness of teachers and principals on leadership characteristics of school Principals. Principals possess reasonable attributes of leadership. At level where the teachers' capabilities are more than the head such a leadership is not useful (Rizwan, 2011). The National Association of Secondary School Principals (NASS) expose the situation faced by headship in public schools in its position paper Principal Shortage (Tracy \& Weaver, 2000), "Principals are dealing with increased job related stress, heightened accountability, new curriculum standards, educating an increasingly diverse student population, addressing social issues that once belonged at home or in the community, while facing possible termination if their schools do not show instant results". This is also true in Pakistani context. If Pakistani schools have to cope to the existing problems, they will need extraordinary educational leaders with extra ordinary leadership skills, such as interactive skills that have become an essential part of valuable leadership. Problems can be reduced and quality can be achieved if administration, teaching staff and board of governors change their attitude towards leadership, team work, collaboration, answerability and gratitude (M. Iqbal \& M. Z. Iqbal, 2011, p. 165). For any successful leader to run an organization effectively he has to plan priory, set goals, motivate teaching staff and encourage student. Lambert (2005, p. 38) added that, "leadership is not a role of a single person but it is actually an organizational concept described as "broad based, skillful participation...that leads to lasting school improvement". Now emphasis is on change both in the literature and in the training programs for head teachers and arrive to a situation where heads feel a change whether it is necessary or not, purely to show leadership. Leadership research has made its generous contribution in the field of education (Muijs, 2011, p. 56). Leadership can be learned and it is not the inborn quality of an individual. Research review shows that there is no sufficient proof, to found a correlation between leadership development and organizational performance (Bush \& Glover, 2004; Muijs, 2011, p. 54). However current literature provides an indirect relationship between leadership development and operational organizational change (Berends et al., 2002; Muijs, 2011, p. 54). Experiential leadership such as coaching and mentoring is related with transformational leadership, while course based leadership development (Traditional university courses) leads to distributive leadership and individual based leadership development (i.e. Distance learning) is refer to transactional leadership (Muijs, 2011, p. 54). Top leaders stop learning, when everything is ok, leaders mostly pinch on learning. Even there is problem takes place; they do not bother to invest in professional development. This means they believe that they know everything. But organizations are always in a state of change. Responding to change always requires learning (Allison, 2012). Similarly (Riaz, 2008, p. 154) articulates that Pakistan is a developing country and its development depend upon various factors, one of them is the education and the foremost factor require for education is the capacity building, which is well explained by (Fullan, 2005, p. 4) as, "capacity building involves developing the collective ability-disposition, skills, knowledge, motivation and resources to act together to bring about positive 
change."

\section{Implications of the Study}

This study has provided insight for the educational leaders that they need to be up-to-dated with skills and abilities. There is no more standby position, need continuous grooming, so they should onboard staff also. Effective leaders know that their journey is not a solo flight, so they use their skills to develop faculty. Transforming school community to accept leadership role and responsibility (Louis et al., 2010, p. 19). Effective leaders are well aware of the fact that how to maintain high performance. They also know the skills to support staff. Effective Principals will take care of six things in fulfilling their responsibilities. These are planning, implementing, supporting, advocating, communicating and monitoring (Porter et al., 2008, p. 15).

\section{Recommendations}

Since school is also an organization like other organizations, to achieve competitive advantage school leaders should throw their inclination towards development of their own capabilities as well as staff capabilities to make schools more effective. This will not only motivate the teachers but also will change their opinion about leadership ability of their principals. Learning is a continuous process and it should continue. Institutes should regularly renew and configure themselves, if they want to stable (Ambrosini et al., 2009, p. 45; Zahra et al., 2006). Dynamic capabilities are institutional process (Ambrosini et al., 2009; Helfat et al., 2007). While learning play a vital role in the creation and promotion of dynamic capabilities, learning itself is a dynamic capability. Dynamic capability is a process which comprises of four steps: reconfiguration, leveraging, learning and integration (Ambrosini et al., 2009; Teece, 2007).

\section{Acknowledgements}

The authors would like to thank to Higher Education Commission of Pakistan \& Shaheed Benazir Bhutto University Dir (U), Khyber Pakhtunkhwa province, Pakistan, for financial support and encouragement.

\section{References}

Alam, S. (2012). Crafting Leaders for Educational Change: Head Teacher's Perspectives about A Tailor Made Professional Development Programme. International Journal of Social Sciences \& Education, 2(1).

Allison, E. (2012). The Resilient Leader. Educational Leadership, 69(4), 79-82.

Ambrosini, V., Bowman, C., \& Collier, N. (2009). Dynamic capabilities: an exploration of how firms renew their $\begin{array}{lllll}\text { resource base. British Journal of Management, } 20(\mathrm{~s} 1), & \text { S9-S24. }\end{array}$ http://dx.doi.org/10.1111/j.1467-8551.2008.00610.x

Arikewuyo, M. O. (2007). Teachers Perception of Principals Leadership Capacities in Nigeria. Academic Leadership Journal, 5(3), 32-39.

Baig, S., \& Shafa, M. D. (2011). The influence of a whole school improvement program on the value orientation of a headteacher in the mountainous region of Gilgit Baltistan, Pakistan. Journal of Authentic Leadership in Education, 2(1), 1.

Banks, C. A. M. (1991). City school superintendents: Their career patterns, traits, and perceptions of leadership and managerial skill and style. Seattle University.

Bell, L., Bolam, R., \& Cubillo, L. (2003). A systematic review of the impact of school headteachers and principals on student outcomes. Review conducted by the School Leadership Review Group, EPPI-Centre, University of London, London.

Berends, M., Bodilly, S., \& Kirby, S. N. (2002). Looking back over a decade of whole-school reform: The experience of New American Schools. Phi Delta Kappan, 168-175. http://dx.doi.org/10.1177/003172170208400214

Bossert, S. T., Dwyer, D. C., Rowan, B., \& Lee, G. V. (1982). The instructional management role of the principal. Educational Administration Quarterly, 18(3), 34-64. http://dx.doi.org/10.1177/0013161X82018003004

Bush, T. (2008). Leadership and management development in education. Sage.

Bush, T., \& Glover, D. (2004). Leadership development: evidence and beliefs.

Cheng, Y. C., \& Townsend, T. (2000). Educational change and development in the Asia-Pacific region: Trends and issues.

Cranston, N. (2002). School-based management, leaders and leadership: change and challenges for principals. International Studies in Educational Administration, 30(1), 2-12. 
Dahar, M. A., Faize, F. A., Niwaz, A., Hussain, M. A., \& Zaman, A. (2010). Relationship between the leadership styles and academic achievement at the secondary stage in Punjab (Pakistan). International Journal of Academic Research, 2(6).

Fullan, M. (2005). Leadership \& sustainability: System thinkers in action. Corwin Press.

Gamage, D. T., \& Pang, N. S.-K. (2003). Leadership and management in education: Developing essential skills and competencies. Chinese University Press.

Hallinger, P. (2003). Leading educational change: Reflections on the practice of instructional and transformational leadership. Cambridge Journal of Education, 33(3), 329-352. http://dx.doi.org/10.1080/0305764032000122005

Hallinger, P., \& Heck, R. H. (1998). Exploring the Principal's Contribution to School Effectiveness: 1980-1995. School Effectiveness and School Improvement, 9(2), 157-191. http://dx.doi.org/10.1080/0924345980090203

Hallinger, P., \& Heck, R. H. (2010). Leadership for learning: Does collaborative leadership make a difference in school improvement? Educational Management Administration \& Leadership, 38(6), 654-678. http://dx.doi.org/10.1177/1741143210379060

Hallinger, P., \& Heck, R. H. (2011). Exploring the journey of school improvement: Classifying and analyzing patterns of change in school improvement processes and learning outcomes. School Effectiveness and School Improvement, 22(1), 1-27. http://dx.doi.org/10.1080/09243453.2010.536322

Harris, A. (2002). Effective leadership in schools facing challenging contexts. School Leadership \& Management, 22(1), 15-26. http://dx.doi.org/10.1080/13632430220143024a

Harris, A. (2007). Distributed leadership: Conceptual confusion and empirical reticence 1. International Journal of Leadership in Education, 10(3), 315-325. http://dx.doi.org/10.1080/13603120701257313

Helfat, C. E., Finkelstein, S., Mitchell, W., Peteraf, M. A., Singh, H., Teece, D. J., \& Winter, S. G. (2007). Dynamic capabilities. Understanding Strategic Change in Organizations.

Hoch, J. E., \& Dulebohn, J. H. (2013). Shared leadership in enterprise resource planning and human resource management system implementation. Human Resource Management Review, 23(1), 114-125. http://dx.doi.org/10.1016/j.hrmr.2012.06.007

Hopkins, D. (2001). School improvement for real. Routledge. http://dx.doi.org/10.4324/9780203165799

Hopkins, D., \& Reynolds, D. (2001). The past, present and future of school improvement: Towards the third age. British Educational Research Journal, 27(4), 459-475. http://dx.doi.org/10.1080/01411920120071461

Hunter-Boykin, H. S., Evans, V., \& Evans, A. M. (1995). The relationship between high school principals' leadership and teachers' morale. Journal of Instructional Psychology.

Iqbal, M., \& Iqbal, M. Z. (2011). Educational Leadership for Managing Quality: Problems, Issues, and Ethical Behavior. Lahore: ICQI.

Khan, A. (2013a). A Case Study of Instructional Contributions of Community and Government Secondary School Administrators in Pakistan. Journal of Education \& Vocational Research, 4(2).

Khan, A. (2013b). A qualitative study of foreign funded capacity development program of head teachers-lessons from Pakistan. European Journal of Business and Social Sciences, 1(12), 107-123.

Khan, H. (2004). Better school management in the Islamic Republic of Pakistan: The role of head teacher. School Principals: Core actors in educational improvement, an analysis of seven Asian countries (pp. 59-113).

Khan, S. H., Saeed, M., \& Fatima, K. (2009). Assessing the Performance of Secondary School Headteachers A Survey Study Based on Teachers' Views in Punjab. Educational Management Administration \& Leadership, 37(6), 766-783. http://dx.doi.org/10.1177/1741143209345572

Kin-Lee, J. C., Walker, A., \& Bodycott, P. (2000). Pre-service Primary Teachers' Perceptions about Principals in Hong Kong: Implications for teacher and principal education. Asia-Pacific Journal of Teacher Education, 28(1), 53-67. http://dx.doi.org/10.1080/135986600109444

Lambert, L. (2002). A framework for shared leadership. Educational Leadership, 59(8), 37-40.

Lambert, L. (2005). What Does Leadership Capacity Really Mean? Journal of Staff Development, 26(2), 38-40.

Leithwood, K., \& Riehl, C. (2003). What do we already know about successful school leadership? AERA 
Division A Task Force on Developing Research in Educational Leadership Report. Washington, DC: American Educational Research Association.

Leithwood, K., Harris, A., \& Hopkins, D. (2008). Seven strong claims about successful school leadership. School leadership and management, 28(1), 27-42. http://dx.doi.org/10.1080/13632430701800060

Louis, K., Leithwood, K., Wahlstrom, K., \& Anderson, S. (2010). Investigating the links to improved student learning: Final Report of Research Findings. University of Minnesota, University of Toronto, and Wallace Foundation.

Luo, M. (2004). Geographic Disparities of Chinese School Principals' Leadership Capacities: A Perspective of Teachers' Perceptions. International Studies in Educational Administration, 32(3).

Luo, M., Huang, W., \& Najjar, L. (2007). The relationship between perceptions of a Chinese high school's ethical climate and students' school performance. Journal of Moral Education, 36(1), 93-111. http://dx.doi.org/10.1080/03057240601185489

Marmar, M. (2001). Total Quality Management in Education. National Institute of Educational Planning and Administration, 1713.

Mattar, D. (2012). Instructional leadership in Lebanese public schools. Educational Management Administration \& Leadership, 40(4), 509-531. http://dx.doi.org/10.1177/1741143212438222

Mestry, R., \& Grobler, B. R. (2004). The Training and Development of Principals to Manage Schools Effectively Using the Competence Approach. International Studies in Educational Administration, 32(3).

Moos, L. (2012). Educational leadership in a competitive state: A contradiction in terms? International Journal of Educational Management, 26(5), 461-469. http://dx.doi.org/10.1108/09513541211240255

Mosadegh-Rad, A. (2003). the role of participative management (suggestion system) in shahid fayazbakhsh hospital effectiveness and efficiency. Journal of Research in Medical Sciences, 8(3).

Muijs, D. (2011). Leadership and organisational performance: From research to prescription? International Journal of Educational Management, 25(1), 45-60.

Niazi, S. (2012). School leadership and educational practices in Pakistan. Dimensions, 1, 5.

Porter, A. C., Murphy, J., Goldring, E., Elliott, S. N., Polikoff, M. S., \& May, H. (2008). Vanderbilt assessment of leadership in education: Technical manual, Version 1.0. Nashville, TN: Vanderbilt University.

Riaz, I. (2008). Schools for change: a perspective on school improvement in Pakistan. Improving Schools, 11(2), 143-156. http://dx.doi.org/10.1177/1365480208091106

Richter, M. M., Lewis, T. J., \& Hagar, J. (2012). The Relationship Between Principal Leadership Skills and School-Wide Positive Behavior Support An Exploratory Study. Journal of Positive Behavior Interventions, 14(2), 69-77. http://dx.doi.org/10.1177/1098300711399097

Rizvi, S. (2010). A Transnational Approach to Educational Leadership Capacity Building: A case study of the masters of education programme at Notre Dame Institute of Education, Karachi, Pakistan. Australian Catholic University.

Rizwan, R. (2011). Role of Leadership at the Head teachers' Level at Urban Primary Government Schools in Developed and Developing Countries: A Case of Schools in Coventry vs. Lahore.

Robinson, V. M., Lloyd, C. A., \& Rowe, K. J. (2008). The impact of leadership on student outcomes: An analysis of the differential effects of leadership types. Educational Administration Quarterly, 44(5), 635-674. http://dx.doi.org/10.1177/0013161X08321509

Scotti Jr, W. H. (1987). Analysis of organizational incongruity using teacher perception of the principal's leadership behavior. Education, 108(1).

Sharma, S., Sun, H., \& Kannan, S. (2012). A Comparative Analysis on Leadership Qualities of School Principals in China, Malaysia \& India. International Online Journal of Educational Sciences, 4(3).

Sharma,S. (2010). Attributes of school principals-leadership qualities. Proceedings International Conference on School Effectiveness \&Improvement (pp. 85-89).

Simkins, T., Sisum, C., \& Memon, M. (2003). School leadership in Pakistan: Exploring the headteacher's role. School Effectiveness and School Improvement, $275-291$. http://dx.doi.org/10.1076/sesi.14.3.275.15841 
Sun, H., Wang, X., \& Sharma, S. (2014). A study on effective principal leadership factors in China. International Journal of Educational Management, 28(6), 716-727. http://dx.doi.org/10.1108/IJEM-11-2013-0173

Tatlah, I. A., Ali, Z., \& Saeed, M. (2011). Leadership behavior and organizational commitment: An empirical study of educational professionals. International Journal of Academic Research, 3(2).

Teece, D. J. (2007). Explicating dynamic capabilities: The nature and microfoundations of (sustainable) enterprise performance. Strategic management journal, 28(13), 1319-1350. http://dx.doi.org/10.1002/smj.640

Tracy, G., \& Weaver, C. (2000). Aspiring leaders academy: Responding to the principal shortage. NASSP bulletin, 84(618), 75-83. http://dx.doi.org/10.1177/019263650008461810

Williams, H. S. (2009). Leadership Capacity-A Key to Sustaining Lasting Improvement. Education, 130(1).

Witziers, B., Bosker, R. J., \& Krüger, M. L. (2003). Educational leadership and student achievement: The elusive search for an association. Educational Administration Quarterly, 39(3), 398-425. http://dx.doi.org/10.1177/0013161X03253411

Zahra, S. A., Sapienza, H. J., \& Davidsson, P. (2006). Entrepreneurship and dynamic capabilities: A review, model and research agenda. Journal of Management studies, 43(4), 917-955. http://dx.doi.org/10.1111/j.1467-6486.2006.00616.x

\section{Copyrights}

Copyright for this article is retained by the author(s), with first publication rights granted to the journal.

This is an open-access article distributed under the terms and conditions of the Creative Commons Attribution license (http://creativecommons.org/licenses/by/3.0/). 